\title{
A probe-based qRT-PCR method to profile immunological gene expression in blood of captive beluga whales (Delphinapterus leucas)
}

\author{
Ming-An Tsai ${ }^{1}$ ， I-Hua Chen ${ }^{2}$, Jiann-Hsiung Wang ${ }^{2}$, Shih-Jen Chou ${ }^{2}$, Tsung-Hsien Li ${ }^{1}$, Ming-Yih Leu ${ }^{1}$, \\ Hsiao-Kuan Ho ${ }^{3}$, Wei Cheng Yang ${ }^{\text {Corresp. } 2}$ \\ 1 Department of Biology, National Museum of Marine Biology and Aquarium, Pingtung, Taiwan \\ 2 College of Veterinary Medicine, National Chiayi University, Chiayi, Taiwan \\ 3 Department of Biology, Hi-Scene World Enterprise Co Ltd., Pingtung, Taiwan \\ Corresponding Author: Wei Cheng Yang \\ Email address: jackywc@gmail.com
}

Cytokines are fundamental for a functioning immune system, and thus, potentially serve as important indicators of animal health. Quantitation of mRNA using quantitative reverse transcription polymerase chain reaction ( $R$ RT-PCR) is an established immunological technique. It is particularly suitable for detecting the expression of proteins against which monoclonal antibodies are not available. In this study, we developed a probe-based quantitative gene expression assay for immunological assessment of captive beluga whales (Delphinapterus leucas) that is one of the most common cetacean species on display in aquariums worldwide. Six immunologically relevant genes (IL-2R $\alpha,-4,-10,-12$, TNF $\alpha$, and IFNY) were selected for analysis, and two validated housekeeping genes (PGK1 and RPL4) with stable expression were used as reference genes. Sixteen blood samples were obtained from four animals with different health conditions and stored in RNAlater solution. These samples were used for RNA extraction followed by qRT-PCR analysis. Analysis of gene transcripts was performed by relative quantitation using the comparative $\mathrm{Cq}$ method with the integration of amplification efficiency and two reference genes. The expression levels of each gene in the samples from clinically healthy animals were normally distributed. Transcript outliers for IL-2R $\alpha$, IL-4, IL-12, TNF $\alpha$, and IFN $\gamma$ were noticed in four samples collected from two clinically unhealthy animals. This assay has the potential to identify immune system deviation from normal state, which is caused by health problems. Furthermore, knowing the immune status of captive cetaceans could help both trainers and veterinarians in implementing preventive approaches prior to disease onset. 


\section{A probe-based qRT-PCR method to profile immunological gene expression in}

\section{2 blood of captive beluga whales (Delphinapterus leucas)}

3

4 Ming-An Tsai ${ }^{1}$, I-Hua Chen ${ }^{2}$, Jiann-Hsiung Wang ${ }^{2}$, Shih-Jen Chou ${ }^{2}$, Tsung-Hsien Li ${ }^{1}$, Ming-Yih

5 Leu ${ }^{1}$, Hsiao-Kuan $\mathrm{Ho}^{3}$, Wei-Cheng Yang ${ }^{2}$

$6{ }^{1}$ Department of Biology, National Museum of Marine Biology and Aquarium, 2 Houwan Road,

7 Checheng, Pingtung, 944, Taiwan.

$8{ }^{2}$ College of Veterinary Medicine, National Chiayi University, 580 Xinmin Road, Chiayi, 600,

9 Taiwan

$10{ }^{3}$ Department of Biology, Hi-Scene World Enterprise Co Ltd., 2 Houwan Road, Checheng,

11 Pingtung, 944, Taiwan.

12 Corresponding author:

13 Wei-Cheng Yang ${ }^{2}$

14 Email address: jackywc@gmail.com 


\section{Abstract}

17 Cytokines are fundamental for a functioning immune system, and thus, potentially serve as

18 important indicators of animal health. Quantitation of mRNA using quantitative reverse

19 transcription polymerase chain reaction (qRT-PCR) is an established immunological technique.

20 It is particularly suitable for detecting the expression of proteins against which monoclonal

21 antibodies are not available. In this study, we developed a probe-based quantitative gene

22 expression assay for immunological assessment of captive beluga whales

23 (Delphinapterus leucas) that is one of the most common cetacean species on display in

24 aquariums worldwide. Six immunologically relevant genes (IL-2R $\alpha,-4,-10,-12, \mathrm{TNF} \alpha$, and

25 IFN $\gamma$ ) were selected for analysis, and two validated housekeeping genes (PGK1 and RPL4) with

26 stable expression were used as reference genes. Sixteen blood samples were obtained from four

27 animals with different health conditions and stored in RNAlater ${ }^{\mathrm{TM}}$ solution. These samples were

28 used for RNA extraction followed by qRT-PCR analysis. Analysis of gene transcripts was

29 performed by relative quantitation using the comparative $\mathrm{Cq}$ method with the integration of

30 amplification efficiency and two reference genes. The expression levels of each gene in the

31 samples from clinically healthy animals were normally distributed. Transcript outliers for IL-

$322 \mathrm{R} \alpha, \mathrm{IL}-4, \mathrm{IL}-12, \mathrm{TNF} \alpha$, and IFN $\gamma$ were noticed in four samples collected from two clinically

33 unhealthy animals. This assay has the potential to identify immune system deviation from normal

34 state, which is caused by health problems. Furthermore, knowing the immune status of captive

35 cetaceans could help both trainers and veterinarians in implementing preventive approaches prior

36 to disease onset. 


\section{Introduction}

40 In recent years, there has been rapid development in the field of cetacean immunology,

41 resulting in new methods to prevent and treat infectious diseases in captive animals being used in

42 education programs and naval defense. Because the free-ranging cetaceans may serve as ideal

43 sentinels of ecosystem health, efforts to develop reliable and relevant immunological techniques

44 to address specific aspects of health and disease have increased (Beineke et al. 2004). Although

45 cetacean species share many key immunological components with lab animals and humans,

46 managing and evaluating the health of cetacean species remain a challenge (Sitt et al. 2008).

47 Leukocyte transcriptional biomarkers such as cytokine genes have potential to assist in cetacean

48 health assessment because of the broad scope of their functions and association with diseases

49 known in human and veterinary medicine (Chaussabel 2015). Cytokines are important in

50 regulating the initiation, maintenance, and amplification of the immune response. Therefore,

51 monitoring and evaluating a set of cytokines expressed within a certain microenvironment can be

52 a diagnostic tool for characterizing immune responses to foreign antigens and vaccines (de Jager

53 et al. 2009). It can also identify perturbations of the immune system induced by environmental

54 insults.

55 Cytokine gene transcripts from several cetacean species have been recently cloned, and their

56 DNA sequences have been determined. Quantitative analyses of cetacean gene transcripts have

57 been reported in beluga whales (Delphinapterus leucas), Pacific white-sided dolphins

58 (Lagenorhynchus obliquidens), bottlenose dolphins (Tursiops truncatus), harbor porpoises

59 (Phocoena phocoena), and killer whales (Orcinus orca) (Beineke et al. 2007; Buckman et al.

60 2011; Mancia et al. 2008; Müller et al. 2013; Sitt et al. 2010; Sitt et al. 2008; Sitt et al. 2016).

61 These studies were based on quantitative reverse transcription polymerase chain reaction (qRT- 
62 PCR) using SYBR Green and various different house-keeping genes (HKGs). These studies

63 enabled better understanding of the relative health of free-ranging cetacean species and in vivo

64 baseline levels of gene expression in captive populations. Because of the short half-lives of

65 leukocyte biomarkers and their tight transcriptional control, identifying disease-specific or

66 antigen-specific patterns of cytokine gene expression could facilitate animal health maintenance.

67 qRT-PCR is a sensitive method commonly used in both basic and diagnostic research to

68 quantify mRNA levels, and to provide informative measures of blood leukocyte gene transcripts.

69 However, only probe-based quantification methods offer minimum non-specific fluorescence

70 and high sensitivity to detect a single gene transcript compared with other dye-based chemistries,

71 enabling an accurate quantification of the amplified targets (Vanysacker et al. 2014). Therefore,

72 probe-based qRT-PCR with validated reference genes is a preferred method for precisely

73 quantifying mRNA abundance and detecting of small changes in gene expression (Wong et al.

74 2015). Here we developed a species-specific probe-based qRT-PCR assay to measure the

75 differential expression of immunologically relevant genes in beluga blood. Our findings could

76 serve as a foundation for using transcriptional biomarkers for diagnosing diseases and assessing

77 immunological profiles in captive and free-ranging cetaceans. 


\section{Materials \& Methods}

80 Sample collection and preservation

81 The voluntary blood collection of captive beluga in the National Museum of Marine Biology

82 and Aquarium was performed according to the international guidelines (Ramirez 1999). The

83 voluntary blood collection means the animal has been trained to present its fluke and allow blood

84 collection when the trainer shows a specific hand signal. When the animal showed reluctance to

85 the voluntary blood draw, the trainers stopped the blood draw procedure and did some other

86 training activity. Animal protocol was reviewed and approved by the Council of Agriculture of

87 Taiwan (Approval number 1020727724). Sixteen blood samples from four 13 17-year-old adult

88 animals (4 from each animal, Table 1) were obtained via venipuncture of the fluke on a monthly

89 basis from 2012 to 2014 . Within five minutes of $1-2 \mathrm{~mL}$ blood being collected, $500 \mu \mathrm{L}$ of

90 EDTA-anticoagulated whole blood was preserved by adding $1.3 \mathrm{~mL}$ RNA stabilization solution

91 (RNAlater ${ }^{\mathrm{TM}}$, Ambion, Applied Biosystems, Foster City, CA, USA). Samples were stored at -20

$92{ }^{\circ} \mathrm{C}$ until analysis. Samples from clinically healthy animals were used for establishing baseline 93 values.

\section{RNA extraction and cDNA synthesis}

The RiboPure ${ }^{\mathrm{TM}}$-Blood Kit (Ambion) was used for total RNA isolation from blood samples

97 according to the manufacturer's instructions. RNase inhibitor (RNA Armor ${ }^{\mathrm{TM}}$ Reagent, Protech,

98 Taipei, Taiwan) was added to the RNA solutions to prevent RNA degradation. RNA integrity

99 was routinely examined using denaturing gel electrophoresis. RNA concentration was measured 
100 using fluorometer assay [Qubit ${ }^{\mathrm{TM}}$ fluorometer with a Quant-iT ${ }^{\mathrm{TM}}$ RNA Assay Kit (Invitrogen,

101 Carlsbad, CA, USA)]. Genomic DNA (gDNA) wipeout solution (Qiagen, Valencia, CA, USA)

102 was added in the RNA samples for gDNA removal, and gDNA contamination was confirmed by

103 qPCR prior to adding reverse transcription reagents. For complementary DNA (cDNA) synthesis,

$10473-444$ ng of RNA and reverse transcription kit (QuantiTect ${ }^{\circledR}$, Qiagen) were used. Unused

105 extracted RNA and cDNA were stored at $-80^{\circ} \mathrm{C}$.

106

107 Primer and probe design

108 The sequences of six immunologically relevant genes (IL-2R $\alpha$, IL-4, IL-10, IL-12, IFN $\gamma$, and

$109 \mathrm{TNF} \alpha$ ) of cetaceans (bottlenose dolphins, Tursiops truncatus) were obtained from GenBank

110 (Table 2). The overall aim was to measure the gene expression of the immune-related activities,

111 including pro-inflammatory, Th1/Th2, T cell growth, and anti-inflammatory features. For the

112 probe-based qRT-PCR assay, a web-based software (ProbeFinder, v.2.49, Roche, Pleasanton,

113 CA, USA) was used for designing specific primers and corresponding probes (Universal

114 ProbeLibrary, Roche) (Table 2). Primer specificity of the six genes was validated using PCR

115 (Fast-Run Hotstart PCR kit, Protech) and electrophoresis. Two validated reference genes (PGK1

116 and RPL4) (Chen et al. 2016) were included for normalization.

117

118 Quantitative PCR 
121 to the manufacturer's protocol. Thermal cycling was conducted using the Eco machine (Illumina,

122 San Diego, CA, USA) and the same conditions were used for all target genes: $95^{\circ} \mathrm{C}$ for $10 \mathrm{~min}$

123 for polymerase activation, followed by 45 cycles of $95^{\circ} \mathrm{C}$ for $10 \mathrm{~s}$ and $60^{\circ} \mathrm{C}$ for $30 \mathrm{~s}$ for

124 denaturation and annealing/elongation, respectively. All reactions including plate controls and

125 blank controls were run in triplicate. Plate controls include identical reaction materials on every

126 run. A stable quantification cycle $(\mathrm{Cq})$ value from all plate controls allowed data from multiple

127 plates to be consolidated into a single data set. Threshold value for each candidate gene was

128 manually set (Table 2). Baseline values were assigned for all plates using the Eco Software V4.0

129 (Illumina). PCR amplification efficiency $(\mathrm{E})$ was calculated as $\mathrm{E}=\left(10^{(-1 / \mathrm{slope})}-1\right) \times 100 \%$,

130 where slope is the gradient of a standard curve. A gene-specific E for the following normalized

131 value (NV) calculation was obtained from the average of at least three E values for each gene.

133 Data analysis

134 Analysis of qRT-PCR data was conducted using NVs modified from Pfaffl et al. (2002): $\log _{2}$

$135\left(\mathrm{E}_{\mathrm{T}}^{\mathrm{CqT}} / \mathrm{Geomean}\left(\mathrm{E}_{\mathrm{R} 1}^{\mathrm{CqR} 1} \& \mathrm{E}_{\mathrm{R} 2}^{\mathrm{CqR} 2}\right)\right)$, where $\mathrm{E}_{\mathrm{T}}, \mathrm{E}_{\mathrm{R} 1}$, and $\mathrm{E}_{\mathrm{R} 2}$ are efficiencies of the target gene

136 and the reference genes, and $\mathrm{CqT}, \mathrm{CqR} 1$, and $\mathrm{CqR} 2$ are $\mathrm{Cq}$ values of the target gene and the

137 reference genes. Lower NVs indicate higher target gene expression levels. Outliers are defined as 
138 values more than the third quartile $+1.5 \times$ IQR or less than the first quartile $-1.5 \times$ IQR, where

139 IQR is the interquartile range. 


\section{Results and Discussion}

142 E values of all the six candidate genes ranged from $93.92 \%$ to $98.99 \%$ with $\mathrm{R}^{2}$ values of

$143>0.99$ (Table 2); therefore all six genes were included in the analysis of NVs. Figure 1 illustrates

144 variable NV levels in the six candidate genes from clinically healthy samples with the lowest

145 median NV (4.63) in IL-2R $\alpha$ and the highest (13.89) in IFN $\gamma$. Gene transcript levels were used to

146 establish three arbitrary categories: IL-2R $\alpha$ (highly transcribed; median NV < 5), IL-10 and

147 TNF $\alpha$ (moderately transcribed), and IFN $\gamma$, IL-4 and IL-12 (poorly transcribed; median NV > 8).

148 Shapiro-Wilk test showed that NV data of each gene was normally distributed $(\mathrm{P}>0.05)$.

149 Stability in NVs during periods of health indicated the potential use in diagnostics by identifying 150 outliers.

151 When pooling all samples (healthy and unhealthy) in one dataset (Table 2), NV outliers in IL-

152 2R $\alpha$, IL-4, IL-12, IFN $\gamma$, and TNF $\alpha$ in four samples (A-I, A-II, C-I, and C-II) from two clinically

153 unhealthy individuals were identified (Fig. 1). NV of IL-12 in sample A-I was 3.03 that is less

154 than the first quartile $-1.5 \times \mathrm{IQR}$, demonstrating that the transcript level of IL-12 was elevated.

$155 \mathrm{NV}$ of IL-2R $\alpha$ in sample A-II was 3.45 , that is less than the first quartile $-1.5 \times$ IQR, revealing

156 that the transcript level of IL-2R $\alpha$ was elevated. NV of IL-4 in sample C-I was 12.91 that is more

157 than the third quartile $+1.5 \times$ IQR, showing that the transcript level of IL-4 was decreased. NVs

158 of IFN $\gamma$, IL-2R $\alpha$, IL-4, and TNF $\alpha$ in sample C-II were 7.91, 5.78, 11.45, and 15.50, revealing

159 that the transcript level of IFN $\gamma$ in this sample was elevated, whereas those of other genes were 
160 decreased.

161 In this study, we selected a panel of genes to cover a wide range of immunological events in

162 beluga. The products of the selected genes are strong mediators of the immune system; they play

163 a key role in the selection of immunological pathways and provide a link between innate and

164 adaptive immune responses. IL-12 is a pro-inflammatory cytokine that induces proliferation and

165 differentiation of T cells (Hsieh et al. 1993). TNFa is another pro-inflammatory cytokine that

166 exerts cytotoxicity and induces cytokine secretion (Clark 2007). It can also restrict the local

167 spreading of infection. The $\alpha$ chain of IL-2 receptor is not expressed on resting T cells but only

168 on activated T cells and is also called T cell activation (TAC) receptor (Liao et al. 2011). IFN $\gamma$ is

169 produced by Th1 cells and shifts the response toward a Th1 phenotype (Schroder et al. 2004). IL-

1704 suppresses the production of Th1 cells and is required for the production of IgE (Sokol et al.

171 2008). IL-10, an important immunoregulatory and anti-inflammatory cytokine (Mosser \& Zhang

172 2008), inhibits the synthesis of a number of cytokines involved in the inflammatory process,

173 including IL-2, TNF $\alpha$ and IFN $\gamma$. It is also a promotor of Th2 response via the suppression of IL-

17412 synthesis. Altogether, the selected genes could reflect the complexity of immunological

175 responses, and their products represent valuable immunological markers.

176 IL-12 in blood is mainly produced by neutrophils and monocytes in response to pathogens

177 (bacteria, fungi, intracellular parasites and viruses)(Trinchieri 2003). IL-2R $\alpha$ expression on

178 leukocytes (neutrophils, NK cells, and activated T helper and regulatory cells) has been reported 
179 as a potential non-specific marker of an activated immune system (Zoldan et al. 2014). Beluga A

180 had open wounds on mandible and several traumas on head, fins, and trunk when sample A-I and

181 A-II were collected, respectively (8-month difference between A-I and A-II collection date,

182 Table 1). Although the blood work and behavior of beluga A did not show obvious signs of

183 infection, the higher expression levels of IL-12 in A-I and IL-2R $\alpha$ in A-II suggested that the

184 immune system was activated as a result of wounds. Sample C-II was obtained when beluga C

185 showed reluctance to the voluntary blood draw. Meanwhile, high fluke temperature was detected

186 by infrared thermography, and vesicles were observed on the fluke of beluga C. Elevated

187 expression levels of IFN $\gamma$ and decreased levels of TNF $\alpha$ in C-II were suggested as normal

188 responses to social stressors in the environment, as previously observed in a killer whale study

189 (Sitt et al. 2016). However, the possibility of an immune response from a virus infection could

190 not be ruled out because of the clinical findings of the fluke. Further virological investigations

191 are ongoing. Sample C-I was taken when beluga C showed reluctance to the voluntary blood

192 draw, and its blood work showed low serum iron level. Decreased expression levels of IL-4 in

193 samples C-I and C-II were unexpected. IL-4 is known to play an important role in Th2 cell-

194 mediated immunity, tissue repair, and homeostasis in human and experimental animals (Gadani

195 et al. 2012). More studies are required to clarify the function of IL-4 in cetaceans.

196 Compared with solid organs, blood is a homogeneous tissue in which cellular composition

197 can considerably vary depending on the location from where the sample is obtained. Without 
198 proper preservation, the copy number of individual mRNA transcripts in blood samples can

199 change more than 1000-fold during storage and transport (Bowen et al. 2012). Two commonly

200 used methods for stabilizing blood RNA are the PAXgene Blood RNA vacutainer tube and

201 RNAlater ${ }^{\mathrm{TM}}$. These methods disrupt cells and precipitate RNA immediately upon

202 homogenization by shaking the evacuated blood collection tubes. The collection tubes can then

203 be stored frozen at $-20{ }^{\circ} \mathrm{C}$ indefinitely without further processing. A previous study on the

204 stability of RNA transcript from blood leukocytes using the above methods showed that both

205 methods were suitable for use based on good quantity, integrity and purity of the isolated RNA

206 (Weber et al. 2010). In this study, we used RNAlater ${ }^{\mathrm{TM}}$ and smaller volume of blood $(0.5 \mathrm{~mL})$ to

207 facilitate sample collection and transportation. Therefore, it was possible to adapt the

208 methodology for serial sampling using small volumes of blood, which provides a temporal

209 perspective transcriptome analysis.

210 It has been assumed that mRNA concentrations are the main determinant of the

211 concentrations and activities of the corresponding proteins (Vogel and Marcotte 2012). One

212 should notice that recent studies showed that mRNA levels may only partially correlate with

213 relative abundances of proteins (reviewed in Vogel and Marcotte 2012) so protein abundances

214 may or may not occur in proportion to their relative mRNA transcript abundances

215 (Ramakrishnan et al. 2009). However, it has been shown that differentially expressed mRNAs

216 correlate significantly better with their protein product than non-differentially expressed mRNAs 
217 (Koussounadis et al. 2015), providing optimism for the usefulness of mRNA data for biological

218 discovery. Probe-based real-time assays with improved specificity are very useful in detecting

219 low abundance cytokines for immunological research. It is particularly suitable for detecting the

220 expression of proteins against which monoclonal antibodies are not available. The detection of

221 cytokine mRNA using qRT-PCR has been suggested to be the only technique sensitive enough

222 for reliable quantification in vivo (Huggett et al. 2005). The widely used SYBR Green assays in

223 previous studies on cetacean gene transcripts have potential limitations such as primer-dimer

224 formation, secondary structure formation by randomly binding to double stranded DNA,

225 overestimate of target DNA, and higher inter-assay variation (Vanysacker et al. 2014). A

226 fluorogenic probe-based approach with enhanced specificity was used in this study to prevent the

227 limitations of SYBR Green assays. Amplification efficiency and reference gene selection are two

228 important factors in gene transcript study using qPCR. The traditional NV is calculated using the

$229 \Delta \mathrm{Cq}$ method $(\mathrm{CqT}-\mathrm{CqR})$. However, the traditional $\Delta \mathrm{Cq}$ method can overestimate the error, and

230 the calculation of the gene expression level requires correction when the amplification efficiency

231 is not close to $100 \%$ (doubling of PCR products per cycle)(Yuan et al. 2008). Moreover, using

232 validated reference genes with stable gene transcript levels in varying experimental conditions

233 can detect small perturbations with good sensitivity (Dheda et al. 2005). In this study, we

234 determined the gene expression profiles by implementing rigorously calculated PCR

235 amplification efficiency (E) and two validated reference genes. This is notably applicable to 
236 clinical sample with high variability and small changes in gene expression.

237 This study established a probe-based qRT-PCR assay for accurate and reliable detection and

238 quantification of six immunologically relevant genes (IL-2R $\alpha$, IL-4, IL-10, IL-12, IFN $\gamma$, and

$239 \mathrm{TNF} \alpha$ ) and two validated reference genes (PGK1 and RPL4) in beluga. The real-time assay was

240 successfully developed using a specific qRT-PCR protocol with the same chemistry and

241 temperature profile, providing a simple and highly sensitive evaluation of normalized gene

242 expression profiles. Preliminary data regarding the immune response of two clinically unhealthy

243 beluga serves as a reference for future studies characterizing a range of health conditions of

244 beluga. This tool for evaluating peripheral blood cytokine gene expression levels in cetaceans

245 would facilitate research on the immune response of animals in the marine habitat in response to

246 environmental insults, as well as the etiology of infectious diseases or stress.

247

248 Acknowledgements

249 We thank the staffs of National Museum of Marine Biology and Aquarium for sample

250 collection. 


\section{References}

253 Beineke A, Siebert U, Müller G, Baumgärtner W. 2007. Increased blood interleukin-10 mRNA

254 levels in diseased free-ranging harbor porpoises (Phocoena phocoena). Veterinary

255 immunology and immunopathology 115:100-106.

256 Beineke A, Siebert U, van Elk N, Baumgartner W. 2004. Development of a lymphocyte257 transformation-assay for peripheral blood lymphocytes of the harbor porpoise and detection of cytokines using the reverse-transcription polymerase chain reaction.

Bowen L, Miles AK, Murray M, Haulena M, Tuttle J, Van Bonn W, Adams L, Bodkin JL, Ballachey B, Estes J, Tinker MT, Keister R, Stott JL. 2012. Gene transcription in sea otters (Enhydra lutris); development of a diagnostic tool for sea otter and ecosystem health. Molecular Ecology Resources 12:67-74.

264

265 266

267 268

269

270

271

272

273

274 Veterinary Immunology and Immunopathology 98:59-68.

Buckman AH, Veldhoen N, Ellis G, Ford JKB, Helbing CC, Ross PS. 2011. PCB-associated changes in mRNA expression in killer whales (Orcinus orca) from the NE Pacific Ocean. Environmental Science \& Technology 45:10194-10202.

Bustin SA, Benes V, Garson JA, Hellemans J, Huggett J, Kubista M, Mueller R, Nolan T, Pfaffl MW, Shipley GL, Vandesompele J, Wittwer CT. 2009. The MIQE guidelines: minimum information for publication of quantitative real-time PCR experiments. Clinical Chemistry 55:611-622.

Chaussabel D. 2015. Assessment of immune status using blood transcriptomics and potential implications for global health. Seminars in Immunology 27:58-66.

Chen IH, Wang JH, Chou SJ, Wu YH, Li TH, Leu MY, Chang WB, Yang WC. 2016. Selection of reference genes for RT-qPCR studies in blood of beluga whales (Delphinapterus 
275 leucas). PeerJ 4:e1810.

276 Clark IA. 2007. How TNF was recognized as a key mechanism of disease. Cytokine and Growth 277 Factor Reviews 18:335-343.

278 de Jager W, Bourcier K, Rijkers GT, Prakken BJ, Seyfert-Margolis V. 2009. Prerequisites for 279 cytokine measurements in clinical trials with multiplex immunoassays. BMC Immunology $280 \quad 10: 52$.

281 Dheda K, Huggett JF, Chang JS, Kim LU, Bustin SA, Johnson MA, Rook GA, Zumla A. 2005.

282 The implications of using an inappropriate reference gene for real-time reverse 283 transcription PCR data normalization. Analytical Biochemistry 344:141-143.

284 Gadani SP, Cronk JC, Norris GT, Kipnis J. 2012. IL-4 in the brain: a cytokine to remember. 285 Journal of Immunology 189:4213-4219.

286 Hsieh C, Macatonia S, Tripp C, Wolf S, O'Garra A, Murphy K. 1993. Development of TH1 287 CD4+ T cells through IL-12 produced by Listeria-induced macrophages. Science $288 \quad 260: 547-549$.

289 Huggett J, Dheda K, Bustin S, Zumla a. 2005. Real-time RT-PCR normalisation; strategies and $290 \quad$ considerations. Genes and Immunity 6:279-284.

291 Koussounadis A, Langdon SP, Um IH, Harrison DJ, Smith VA. 2015. Relationship between 292 differentially expressed mRNA and mRNA-protein correlations in a xenograft model $293 \quad$ system. Scientific Reports 5:10775.

294 Liao W, Lin JX, Leonard WJ. 2011. IL-2 family cytokines: new insights into the complex roles 295 of IL-2 as a broad regulator of T helper cell differentiation. Current Opinion in 296 Immunology 23:598-604.

297 Mancia A, Warr GW, Chapman RW. 2008. A transcriptomic analysis of the stress induced by 
capture-release health assessment studies in wild dolphins (Tursiops truncatus). Molecular Ecology 17:2581-2589.

300 Mosser DM, Zhang X. 2008. Interleukin-10: new perspectives on an old cytokine.

$301 \quad$ Immunological Reviews 226:205-218.

302 Müller S, Lehnert K, Seibel H, Driver J, Ronnenberg K, Teilmann J, van Elk C, Kristensen J, 303 Everaarts E, Siebert U. 2013. Evaluation of immune and stress status in harbour 304 porpoises (Phocoena phocoena): can hormones and mRNA expression levels serve as indicators to assess stress? BMC Veterinary Research 9:1-12.

306

307

308

309

310

311

312

313

314

315

316

317

318

319

Pfaffl MW, Horgan GW, Dempfle L. 2002. Relative expression software tool (REST) for groupwise comparison and statistical analysis of relative expression results in real-time PCR. Nucleic Acids Research 30:e36.

Ramakrishnan SR, Vogel C, Prince JT, Li Z, Penalva LO, Myers M, Marcotte EM, Miranker DP, Wang R. 2009. Integrating shotgun proteomics and mRNA expression data to improve protein identification. Bioinformatics 25:1397-1403.

Ramirez K. 1999. Animal Training: Successful Animal Management Through Positive Reinforcement. Chicago: Shedd Aquarium Society.

Schroder K, Hertzog PJ, Ravasi T, Hume DA. 2004. Interferon- $\gamma$ : an overview of signals, mechanisms and functions. Journal of Leukocyte Biology 75:163-189.

Sitt T, Bowen L, Blanchard MT, Gershwin LJ, Byrne Ba, Dold C, McBain J, Stott JL. 2010. Cellular immune responses in cetaceans immunized with a porcine erysipelas vaccine. Veterinary Immunology and Immunopathology 137:181-189.

Sitt T, Bowen L, Blanchard MT, Smith BR, Gershwin LJ, Byrne BA, Stott JL. 2008. Quantitation of leukocyte gene expression in cetaceans. Developmental and Comparative 
Immunology 32:1253-1259.

322 Sitt T, Bowen L, Lee CS, Blanchard MT, McBain J, Dold C, Stott JL. 2016. Longitudinal

323

324

325

326

327 328

329

330

331

332

333

334

335

336

337

338

339

340

341

342

343 evaluation of leukocyte transcripts in killer whales (Orcinus Orca). Veterinary Immunology and Immunopathology 175:7-15.

Sokol CL, Barton GM, Farr AG, Medzhitov R. 2008. A mechanism for the initiation of allergeninduced T helper type 2 responses. Nature Immunology 9:310-318.

Trinchieri G. 2003. Interleukin-12 and the regulation of innate resistance and adaptive immunity. Nature Reviews Immunology 3:133-146.

Vanysacker L, Denis C, Roels J, Verhaeghe K, Vankelecom IF. 2014. Development and evaluation of a TaqMan duplex real-time PCR quantification method for reliable enumeration of Candidatus Microthrix. Journal of Microbiological Methods 97:6-14.

Vogel C and Marcotte EM. 2012. Insights into the regulation of protein abundance from proteomic and transcriptomic analyses. Nature Reviews Genetics 13:227-232.

Weber DG, Casjens S, Rozynek P, Lehnert M, Zilch-Schoneweis S, Bryk O, Taeger D, Gomolka M, Kreuzer M, Otten H, Pesch B, Johnen G, Bruning T. 2010. Assessment of mRNA and microRNA stabilization in peripheral human blood for multicenter studies and biobanks. Biomarker Insights 5:95-102.

Wong W, Farr R, Joglekar M, Januszewski A, Hardikar A. 2015. Probe-based real-time PCR approaches for quantitative measurement of microRNAs. Journal of Visualized Experiment 98: e52586.

Yuan JS, Wang D, Stewart CN. 2008. Statistical methods for efficiency adjusted real-time PCR quantification. Biotechnology Journal 3:112-123.

Zoldan K, Moellmer T, Schneider J, Fueldner C, Knauer J, Lehmann J. 2014. Increase of CD25 
expression on bovine neutrophils correlates with disease severity in post-partum and 
349 Table 1 Sample description.

\begin{tabular}{llllll}
\hline Animal & Sex & $\begin{array}{l}\text { Age } \\
\text { (years) }\end{array}$ & $\begin{array}{l}\text { No. of healthy samples } \\
\text { (collection date: } \\
\text { year/month) }\end{array}$ & $\begin{array}{l}\text { No. of unhealthy } \\
\text { samples (collection date: } \\
\text { year/month) }\end{array}$ & Notes \\
\hline A & Female & $\sim 17$ & $2(2012 / 12 ; 2014 / 01)$ & $2(2013 / 01,09)$ & Open wounds \\
B & Male & $\sim 17$ & $4(2013 / 01,02,08,09)$ & 0 & $2(2013 / 03 ; 2014 / 05)$ \\
C & Female & $\sim 13$ & $2(2013 / 04,12)$ & & $\begin{array}{l}\text { Vesicles on } \\
\text { fluke, low } \\
\text { serum iron } \\
\text { level }\end{array}$ \\
\hline D & & & & & \\
\hline
\end{tabular}


351 Table 2 Name, accession number, primer sequence, probe number, amplicon size, efficiency and $\mathrm{R}^{2}$ of 6 immunologically relevant 352 genes.

\begin{tabular}{|c|c|c|c|c|c|c|c|}
\hline $\begin{array}{l}\text { Gene } \\
\text { Name }\end{array}$ & $\begin{array}{l}\text { Accession } \\
\text { Number }\end{array}$ & Primer Sequence (5'-3') & $\begin{array}{l}\text { UPL } \\
\text { Probe } \\
\text { Number }\end{array}$ & $\begin{array}{l}\text { Amplicon } \\
\text { Size (bp) }\end{array}$ & Threshold & $\begin{array}{l}\text { Efficiency } \\
(\%) \pm S D\end{array}$ & $\mathbf{R}^{2}$ \\
\hline IL-2Ra & $\mathrm{XM}=00431350$ & $\begin{array}{l}\text { F-TGAACCTTTGAAGAGAATTTACCA } \\
\text { R-CTGAATCCCTGAATGCACTG }\end{array}$ & 112 & 72 & 0.015 & $98.99 \pm 1.25$ & 0.998 \\
\hline IL-4 & NM_00128065 & $\begin{array}{c}\text { F-GCATGGAGCTGCCTGTAGA } \\
\text { R-TGCAGAAAGTTTCCTTCTCAGTT }\end{array}$ & 140 & 69 & 0.012 & $93.92 \pm 1.83$ & 0.995 \\
\hline IL-10 & AB775207.1 & $\begin{array}{l}\text { F-AAGCCCTGTCGGAGATGAT } \\
\text { R-CACGTGCTCTTTGATGTTGG }\end{array}$ & 25 & 86 & 0.012 & $97.25 \pm 3.61$ & 0.995 \\
\hline IL-12 & $\begin{array}{l}\mathrm{XM} \_00432440 \\
2.1\end{array}$ & $\begin{array}{l}\text { F-CAGAAGGAGCTCTTTTATGACGA } \\
\text { R-CCATGTGGTACATCTTCAAGTCC }\end{array}$ & 98 & 71 & 0.015 & $93.95 \pm 3.04$ & 0.997 \\
\hline TNF- $\alpha$ & NM_00128061 & $\begin{array}{c}\text { F-CCAACTGGCTACTCCATCATC } \\
\text { R-CGGGCTTGTTACTTGAGGTT }\end{array}$ & 106 & 76 & 0.012 & $94.44 \pm 2.00$ & 0.997 \\
\hline IFN-Y & AB022044.2 & $\begin{array}{c}\text { F-TTTTCAGCTATGCGTGATTTTG } \\
\text { R- } \\
\text { TGCATTAAAATATTCCTTTAGGTTTTG }\end{array}$ & 129 & 94 & 0.010 & $95.78 \pm 2.83$ & 0.997 \\
\hline
\end{tabular}




\section{Figure Legends}

355

356 Figure 1 Box plot of normalized value (NV) of 6 immunologically relevant genes for blood samples from clinically healthy ( $\mathrm{n}=12$ )

357 and symptomatic ( $\mathrm{n}=4$, outliers) belugas. The rectangle represents the second and third quartiles and the vertical line inside indicates

358 the median value. The lower and upper quartiles are shown as horizontal lines either side of the rectangle. Open circle: sample A-I;

359 closed circle: sample A-II; triangle: sample C-I; asterisk: sample C-II. 


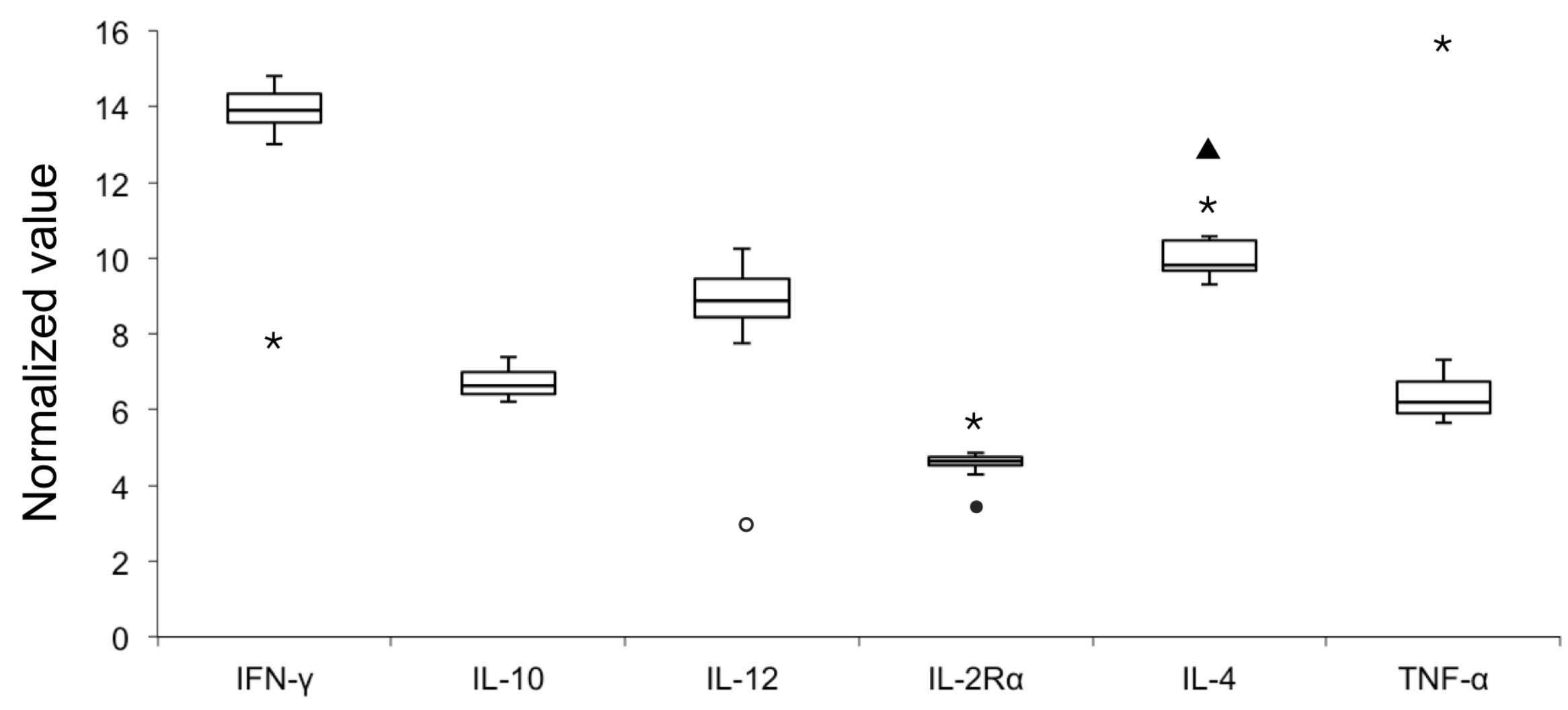

